\title{
Genotyping of Shiga-like toxin genes in non-0157 Escherichia coli strains associated with haemolytic uraemic syndrome
}

\author{
H. RÜSSMANN, E. KOTHE, H. SCHMIDT, S. FRANKE, D. HARMSEN, A. CAPRIOLI* \\ and H. KARCH†
}

Institut für Hygiene und Mikrobiologie der Universität Würzburg, Bau 17, Josef-Schneider-Str. 2, 97080 Würzburg, Germany and * Laboratorio di Ultrastrutture, Istituto Superiore di Sanità, Viale Regina Elena, 229, 00161 Rome, Italy

\begin{abstract}
Summary. The pheno- and genotypes of Shiga-like toxins (SLTs) in non-O157 Escherichia coli strains from patients with haemolytic uraemic syndrome were determined. The clinical isolates investigated were from Italy and Germany and belonged to serotypes $\mathrm{O} 22: \mathrm{H} 8$, $\mathrm{O} 26: \mathrm{H}^{-}, \mathrm{O} 26: \mathrm{H} 11, \mathrm{O} 91: \mathrm{H}^{-}, \mathrm{O} 111: \mathrm{H}^{-}$and $\mathrm{O} 128: \mathrm{H}^{-}$; one isolate was non-typable. SLT genotypes were analysed by complete nucleotide sequence analysis of the B-subunit genes. The results showed that 14 strains possessed slt-I alone, two contained slt-II alone and five isolates harboured both slt-I and slt-II genes. In only two strains were slt-II-related genes found, together with either slt-I or slt-II. These findings indicate that variants of SLT-II are rarely found in non-O157 E. coli isolates from patients with haemolytic uraemic syndrome. Polymerase chain reaction (PCR) with Taq cycle sequencing was found to be a suitable method for classification of slt genotypes.
\end{abstract}

\section{Introduction}

Haemolytic uraemic syndrome (HUS) is the leading form of acute renal failure in children. Among the various forms of HUS, the classical one, which typically follows a prodrome of acute gastroenteritis, is the most frequent. Shiga-like toxin (SLT, verocytotoxin)-producing Escherichia coli strains are recognised as the major cause of this disease. ${ }^{1}$ Many serogroups of E. coli other than 0157 have been implicated in sporadic cases of HUS. ${ }^{1-9}$ The first outbreak of HUS associated with non-O157 SLTproducing $E$. coli has been described recently. ${ }^{10}$ Serotyping revealed that the isolates belonged to serotype $\mathrm{O} 111: \mathrm{H}^{-}$.

Immunological and molecular analysis of the SLTs produced by $E$. coli have shown that, in addition to the prototypes SLT-I and SLT-II, variants of SLT-II exist both in E. coli $\mathrm{O} 157$ and non-O157 strains. ${ }^{11}$ SLT-IIrelated toxins exhibit only partial serological crossreactivity with SLT-II and are less toxic to HeLa cells than to Vero cells. The genes for the variants of SLTII associated with human diseases are termed $s l t-I I c,{ }^{12}$ slt-IIvhc, ${ }^{13}$ slt-IIva ${ }^{14}$ vt $x 2 h a$ and vt $x 2 h b .{ }^{15}$ Recently, additional SLT-II variants have been described,

Received 14 Oct. 1994; accepted 23 Dec. 1994

$\dagger$ Correspondence should be sent to Professor H. Karch. suggesting great heterogeneity among the toxins belonging to the SLT-II family. ${ }^{16,17}$ Because there is insufficient nucleotide heterogeneity within the slt-II locus to permit detection of variants with polynucleotide probes, SLT-II variants were previously undetectable. We have demonstrated the impact of polymerase chain reaction (PCR) technology and subsequent restriction endonuclease analysis by finding slt-II-related genes among 17 of 38 strains of E. coli $\mathrm{O} 157$ from patients with HUS. ${ }^{18}$

Little is known about the association between SLTII variants of non-O157 E. coli strains and disease or their prevalence in $E$. coli strains isolated from defined diseases such as HUS. Therefore, in this study, the slt genotypes were determined in non-O157 E. coli strains associated with HUS and the combination of PCR technology with the Taq cycle sequencing method was examined for the rapid and precise classification of $s l t$ genes.

\section{Material and methods}

\section{Bacterial strains}

The 23 non-O157 E. coli strains investigated in this study are listed in table I. All strains were isolated from HUS patients in Germany during 1985-1992 or in Italy during 1989-1993. Some of these strains have 
Table I. The slt genotypes found in non-O157 E. coli strains associated with HUS

\begin{tabular}{|c|c|c|c|}
\hline Strain no. & Origin & Serotype & slt genotype \\
\hline HUS-2/85 & Germany & $\mathrm{O} 111: \mathrm{H}^{-}$ & slt-I \\
\hline $4924 / 85$ & Germany & $\mathrm{O} 111: \mathrm{H}^{-}$ & slt-I \\
\hline $4321 / 86$ & Germany & $\mathrm{O} 111: \mathrm{H}^{-}$ & slt-I \\
\hline $3217 / 86$ & Germany & $\mathrm{O} 111: \mathrm{H}^{-}$ & slt-I \\
\hline $3222 / 87$ & Germany & $\mathrm{O} 111: \mathrm{H}^{-}$ & slt-I \\
\hline $7042 / 87$ & Germany & $\mathrm{O} 111: \mathrm{H}^{-}$ & slt-I, slt-II \\
\hline $5736 / 88$ & Germany & $\mathrm{O} 111: \mathrm{H}^{-}$ & slt-I \\
\hline $4856 / 88$ & Germany & $\mathrm{O} 111: \mathrm{H}^{-}$ & slt-I \\
\hline $1899 / 90$ & Germany & $\mathrm{O} 111: \mathrm{H}^{-}$ & slt $-I$ \\
\hline $928 / 91$ & Germany & $\mathrm{O} 111: \mathrm{H}^{-}$ & slt $-I$, slt $-I I$ \\
\hline $78 / 92$ & Germany & $\mathrm{O} 111: \mathrm{H}^{-}$ & slt-I \\
\hline $472 / 92$ & Germany & $\mathrm{O} 111: \mathrm{H}^{-}$ & slt-I, slt-II \\
\hline E-D31 & Italy & $\mathrm{O} 111: \mathrm{H}^{-}$ & slt $-I$, slt $-I I$ \\
\hline E-D82 & Italy & $\mathrm{O} 111: \mathrm{H}^{-}$ & slt $-I$ \\
\hline E-D142 & Italy & $\mathrm{O} 111: \mathrm{H}^{-}$ & slt $-I$, slt $-I I$ \\
\hline $4478 / 85$ & Germany & $\mathrm{O} 26: \mathrm{H} 11$ & slt $-I$ \\
\hline E-D147 & Italy & $\mathrm{O} 26: \mathrm{H} 11$ & slt-II \\
\hline $6769 / 89$ & Germany & $\mathrm{O} 26: \mathrm{H}^{-}$ & slt $-I$ \\
\hline E-D17 & Italy & $\mathrm{O} 26: \mathrm{H}^{-}$ & slt-I \\
\hline $469 / 87$ & Germany & $\mathrm{O} 22: \mathrm{H} 8$ & slt-I, slt-IIvhc \\
\hline $284 / 89$ & Germany & $\mathrm{O} 128: \mathrm{H}^{-}$ & slt-II \\
\hline $2343 / 89$ & Germany & $\mathrm{O} 91: \mathrm{H}^{-}$ & slt $-I$ \\
\hline $199 / 92$ & Germany & $\mathrm{ONT}: \mathrm{H}^{-}$ & slt-II, slt-IIvhc \\
\hline
\end{tabular}

ONT, not O serotypable.

been described before. ${ }^{2,8,10,19-23}$ Eleven of the strains were identified by cytotoxicity assays with Vero cells ${ }^{19}$, and 12 strains by colony blot hybridisation with oligonucleotide probes 772 and $849^{24}$ as described previously. Probe 849 has been shown to identify slt-II and its variant forms. ${ }^{24}$

\section{Amplification of slt genes}

The primers and PCR conditions used to specifically amplify slt genes are given in table II. Bacterial DNA was prepared by incubating $10 \mu \mathrm{l}$ of a bacterial suspension $\left(10^{4}\right.$ bacteria) for $10 \mathrm{~min}$ at $95^{\circ} \mathrm{C}$. Amplifications were performed in a total volume of $50 \mu \mathrm{l}$ containing $200 \mu \mathrm{M}$ deoxynucleoside triphosphates (dATP, dCTP, dGTP and dTTP), $30 \rho$ mol of each primer, $5 \mu$ l of 10 -fold concentrated polymerase synthesis buffer and $2.5 \mathrm{U}$ of Taq-DNA-polymerase (Amersham Laboratories, Buckinghamshire).

\section{Southern hybridisation and digoxigenin labelling of the} slt-II probes by $P C R$

Southern hybridisation was performed as described previously. ${ }^{25}$ Briefly, labelled slt-IIB probes were generated with $T a q$-DNA-polymerase by specifically primed incorporation of digoxigenin-11-dUTP during PCR. Generation of digoxigenin-labelled probes was performed in a total volume of $50 \mu$ containing dATP, $\mathrm{dCTP}$ and dGTP at $200 \mu \mathrm{M}$, a mixture comprising $130 \mu \mathrm{M}$ dTTP and $70 \mu \mathrm{M}$ digoxigenin-11-deoxyuridinetriphosphate (Dig-11-dUTP), $30 \rho$ mol each of primer GK3 and GK4, $5 \mu$ l of 10-fold concentrated polymerase synthesis buffer and $2.5 \mathrm{U}$ of Taq-DNApolymerase.

\section{Restriction endonuclease analysis}

After PCR amplification with primers GK3/GK4, restriction endonuclease analysis of the products was performed with HaeIII and FokI to distinguish between $s l t-I I B$ and slt-IIB-related sequences. Briefiy, $10-\mu 1$ volumes of the amplified products were digested with HaeIII and FokI as recommended by the suppliers (Boehringer GmbH, Mannheim, Germany). The DNA fragments from restriction endonuclease digestion were separated and visualised as described above. Based on the published sequences of $s l t-I I B$ and $s l t-I I c B,{ }^{12}$ restriction endonuclease digestion of the slt$I I B$ PCR product with FokI should yield two fragments of $115 \mathrm{bp}$ and $155 \mathrm{bp}$, whereas the slt-IIcB PCR product should remain undigested. Conversely, restriction endonuclease digestion of the slt-IIBrelated amplification product with HaeIII should yield a 128-bp and a 142-bp fragment. The small fragments (116 bp and $154 \mathrm{bp} ; 128 \mathrm{bp}$ and $142 \mathrm{bp}$ ) were not separable in this gel system.

\section{Nucleotide sequence analysis by Taq cycle sequencing}

Before sequence analysis, digestion of the PCR products was performed with FokI or HaeIII, which

Table II. Designation and sequences of the primers and PCR conditions used for amplification of slt genes

\begin{tabular}{|c|c|c|c|c|c|}
\hline \multirow{2}{*}{$\begin{array}{l}\text { Primer } \\
\text { designation }\end{array}$} & \multirow{2}{*}{ Primer sequences } & \multirow{2}{*}{$\begin{array}{l}\text { Genes } \\
\text { amplified }\end{array}$} & \multicolumn{3}{|c|}{ PCR conditions } \\
\hline & & & Denaturing & Annealing & Extension \\
\hline $\begin{array}{l}\text { KS7 } \\
\text { KS8 }\end{array}$ & $\begin{array}{l}5^{\prime} \text {-CCC GGA TCC ATG AAA AAA ACA TTA TTA ATA GC-3' } \\
5^{\prime} \text {-CCC GAA TTC AGC TAT TCT GAG TCA ACG-3' }\end{array}$ & slt $-I B$ & $94^{\circ} \mathrm{C}, 30 \mathrm{~s}$ & $\begin{array}{l}52^{\circ} \mathrm{C}, 60 \mathrm{~s} \\
30 \text { cycles }\end{array}$ & $72^{\circ} \mathrm{C}, 40 \mathrm{~s}$ \\
\hline $\begin{array}{l}\text { GK3 } \\
\text { GK4 }\end{array}$ & $\begin{array}{l}5^{\prime}-\mathrm{CCC} \text { GGA TCC ATG AAG AAG ATG TTT ATG GCG-3' } \\
5^{\prime} \text {-CCC GAA TTC TCA GTC ATT ATT AAA CTG CAC-3' }\end{array}$ & $\begin{array}{l}\text { slt-IIB } \\
\text { slt-IIcB } \\
\text { slt-IIvhaB } \\
\text { slt-IIvhbB }\end{array}$ & $94^{\circ} \mathrm{C}, 30 \mathrm{~s}$ & $\begin{array}{l}52^{\circ} \mathrm{C}, 60 \mathrm{~s} \\
30 \text { cycles }\end{array}$ & $72^{\circ} \mathrm{C}, 40 \mathrm{~s}$ \\
\hline $\begin{array}{l}\text { FK1 } \\
\text { FK2 }\end{array}$ & $\begin{array}{l}5^{\prime}-\mathrm{CCC} \text { GGA TCC AAG AAG ATG TTT ATA G-3' } \\
5^{\prime} \text {-CCC GAA TTC TCA GTT AAA CTT CAC C-3' }\end{array}$ & slt-IIeB & $94^{\circ} \mathrm{C}, 30 \mathrm{~s}$ & $\begin{array}{l}53^{\circ} \mathrm{C}, 60 \mathrm{~s} \\
30 \text { cycles }\end{array}$ & $72^{\circ} \mathrm{C}, 40 \mathrm{~s}$ \\
\hline $\begin{array}{l}\text { FK5 } \\
\text { FK6 }\end{array}$ & $\begin{array}{l}\text { 5'-ATG AAG AAG ATA TTT GTA GCG-3' } \\
\text { 5'-TTA ATT AAA CTG CAC TTC AGC-3' }\end{array}$ & $\begin{array}{l}\text { slt-IIOX3B } \\
\text { slt-IIOIIIB }\end{array}$ & $94^{\circ} \mathrm{C}, 30 \mathrm{~s}$ & $\begin{array}{l}52^{\circ} \mathrm{C}, 60 \mathrm{~s} \\
30 \text { cycles }\end{array}$ & $72^{\circ} \mathrm{C}, 40 \mathrm{~s}$ \\
\hline $\begin{array}{l}\text { FK7 } \\
\text { FK8 }\end{array}$ & $\begin{array}{l}\text { 5'-ATG AAG AAG ATG ATT ATT GCA-3' } \\
5^{\prime} \text {-TCA GTT AAA CTT CAC CTG GGC-3' }\end{array}$ & slt-IIvaB & $94^{\circ} \mathrm{C}, 30 \mathrm{~s}$ & $\begin{array}{l}52^{\circ} \mathrm{C}, 60 \mathrm{~s} \\
30 \text { cycles }\end{array}$ & $72^{\circ} \mathrm{C}, 40 \mathrm{~s}$ \\
\hline
\end{tabular}


selectively digested $s l t-I I B$ and slt-IIB-related genes, respectively, and the process was repeated to eliminate any small quantities of undigested slt-II or slt-IIBrelated genes. Gel slices with the digested fragments were excised and the DNA was purified with the PrepA-Gene kit as described by the manufacturer (BioRad, Munich, Germany). A total of $2 \mu \mathrm{g}$ of the doublestranded PCR product was subjected to Taq cycle sequencing reactions with the Prism Ready Reaction DyeDeoxy Terminator Cycle Sequencing kit (Applied Biosystems, Darmstadt, Germany). Briefly, $9 \cdot 5 \mu \mathrm{l}$ of terminator premix, $2 \mu \mathrm{g}$ of template DNA, $3 \cdot 2 \rho \mathrm{mol}$ each of primer GK3 and GK4 were mixed in a $0 \cdot 6-\mathrm{ml}$ reaction tube and made up with distilled water to a final volume of $20 \mu \mathrm{l}$. The tubes were placed in a thermal cycler preheated to $96^{\circ} \mathrm{C}$ and subjected to 25 cycles with the following parameters: $96^{\circ} \mathrm{C}$ for $15 \mathrm{~s}$, $52^{\circ} \mathrm{C}$ for $15 \mathrm{~s}$ and $60^{\circ} \mathrm{C}$ for $4 \mathrm{~min}$. The cycle sequencing products were extracted with phenol-chloroform and precipitated with ethanol. The resulting DNA pellets were dissolved in $4 \mathrm{ml}$ of a mixture of formamide and $50 \mathrm{~mm}$ EDTA, pH 8.0, (5:1). Separation of sequencing products was performed on denaturing polyacrylamide $7 \%$ gels in an automatic sequencer (Model 373 A, Applied Biosystems). Nucleotide sequencing was performed in triplicate and analysed with the DNASIS program, version 2.0 from Hitachi Software (San Bruno, CA, USA). To overcome sequencing mistakes generated by Taq-DNA-polymerase, both strands of the PCR products were analysed with primers GK 3 and GK4 as sequencing primers.

\section{Cytotoxicity test and neutralisation assay}

Culture filtrates were tested for cytotoxic activity on Vero cells ${ }^{19}$ and neutralisation assays ${ }^{25}$ were performed as described previously.

\section{Results}

\section{$P C R$ strategy and restriction fragment length polymorphism for genotyping SLTS}

To subdivide the $23 \mathrm{E}$. coli strains according to their slt genes, each isolate was subjected to PCR analysis with the primers listed in table II. No PCR product was obtained with the primer pairs FK1/FK2, FK5/FK6 and FK7/FK8. However, 20 of the $23 E$. coli strains showed a positive PCR result with the slt-IB-specific primer pair KS7/KS8. Nine of the 23 isolates yielded a positive PCR result with primers GK3/GK4 that identify both slt-IIB and the related subunit genes slt-IIcB, vtx2haB and $v t x 2 h b B$. Five of these nine isolates were of $E$. coli serotype $\mathrm{O} 111: \mathrm{H}^{-}$, one was E. coli $O 22: H 8$, one was E. coli $\mathrm{O} 128: \mathrm{H}^{-}$, one was $E$. coli $\mathrm{O} 26: \mathrm{H} 11$ and one strain was not typable. The PCR products of these nine isolates analysed on agarose gels yielded DNA bands of $c .270 \mathrm{bp}$.

\section{Restriction endonuclease analysis}

For further characterisation, the 270-bp DNA bands of the nine isolates were subjected to restriction endonuclease analyses with $\mathrm{HaeIII}$ and FokI, which selectively digest slt-II-related genes and slt-II, respectively. Fig. 1, lanes 1-6, shows representative fragment patterns resulting from digestion with FokI, and lanes 7-12 with HaeIII. It can be seen that the PCR products of four isolates were digested with FokI into two smaller fragments (fig. 1, lanes 1, 3, 4 and 6). The digestion patterns of these PCR products with HaelII are depicted in fig. 1, lanes 7, 9, 10 and 12. The PCR fragment of only the E. coli $\mathrm{O} 22: \mathrm{H} 8$ strain 469/87 remained undigested with FokI (fig. 1, lane 2), but was digested with HaeIII (fig. 1, lane 8). Fig. 1, lanes 5 and 11, shows both digested and undigested fragment bands for the PCR products of strain 199/92

\section{$\begin{array}{lllllllllllll}1 & 2 & 3 & 4 & 5 & 6 & 7 & 8 & 9 & 10 & 11 & 12 & M\end{array}$}

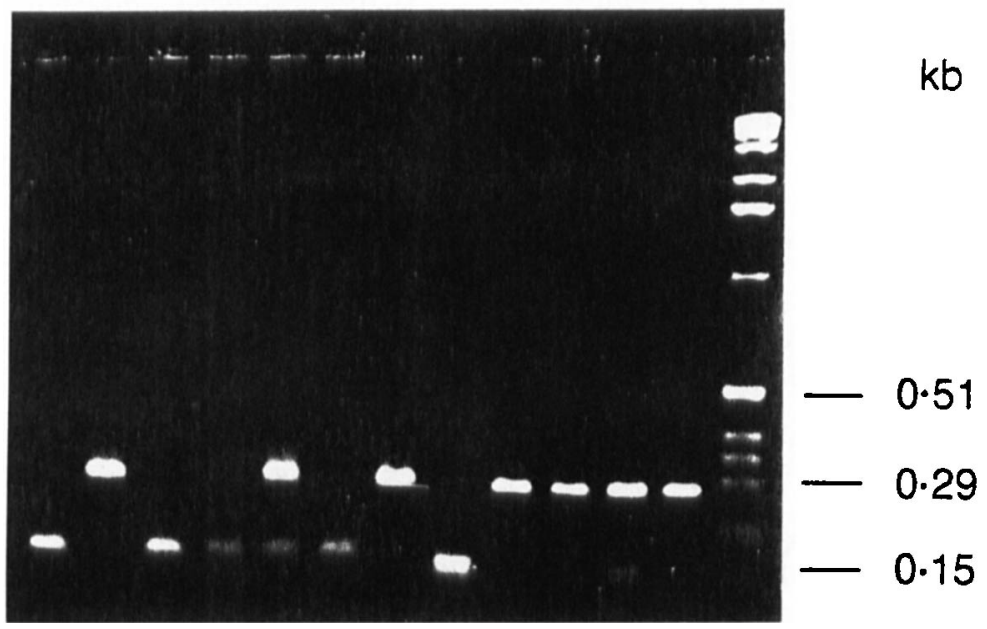

Fig. 1. Agarose gel electrophoresis of representative fragments obtained by PCR with primers GK3/GK4 which were subsequently subjected to restriction endonuclease analysis with FokI (lanes 1-6) or HaeIII (lanes 7-12). The PCR fragments analysed were from the following strains: lane $1,7042 / 87 ; \mathbf{2}, 469 / 87 ; \mathbf{3}, 928 / 91 ; \mathbf{4}, 472 / 92 ; \mathbf{5}, 199 / 92 ; \mathbf{6}, 284 / 89 ; 7,7042 / 87 ; 8,469 / 87 ; 9,928 / 91 ; 10,472 / 92 ; 11,199 / 92$; 12, 284/89; M, DNA mol.-wt markers. 
atgaagaagatgtttatggcggttttatttgcattagcttctgtaaatgc

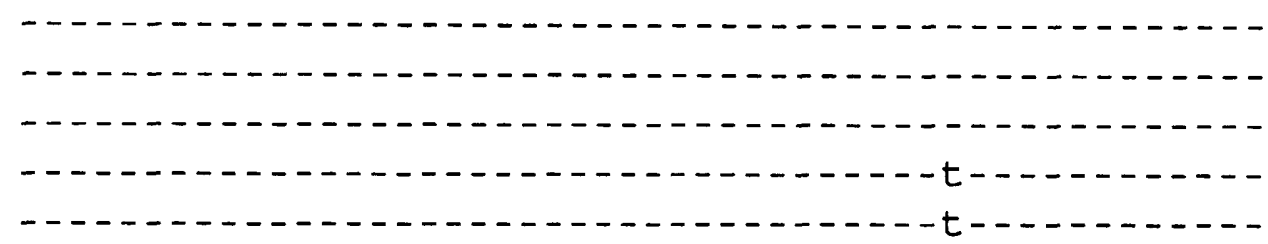

$472 / 92$

aatggcggcggattgtgctaaaggtaaattgagttttccaagtataatg aggatgacacatttacagtgaaggttgacgggaaagaatactggaccagt

$284 / 89$

$199 / 92^{a}$

$199 / 92^{b}$

$469 / 87$

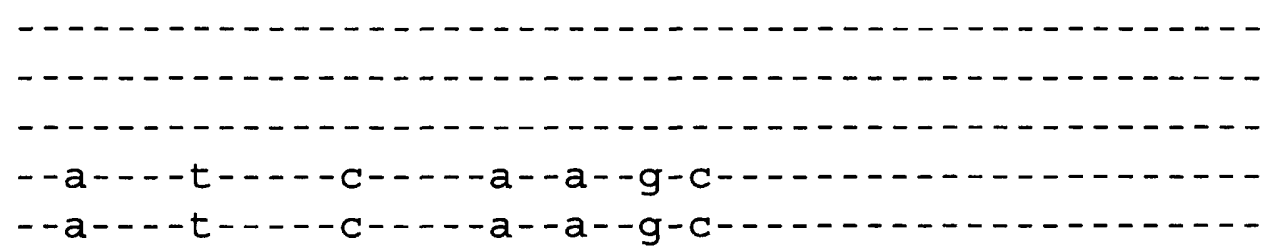

200 cgctggaatctgcaaccgttactgcaaagtgctcagttgacaggaatgac

$472 / 92$

$284 / 89$

$199 / 92^{a}$

$199 / 92^{b}$

$469 / 87$

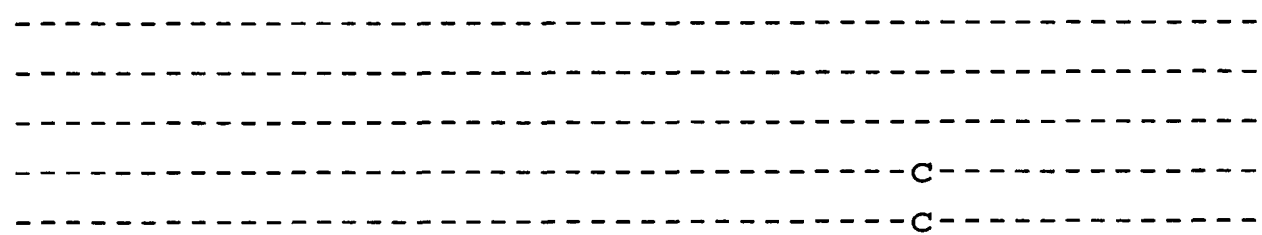

250

tgtcacaatcaaatccagtacctgtgaatcaggctccggatttgctgaag

$472 / 92$

$284 / 89$

$199 / 92^{a}$

$199 / 92^{b}$

$469 / 87$

$472 / 92$

\section{0}

$284 / 89$

$199 / 92^{a}$

$199 / 92^{b}$

$469 / 87$

Fig. 2. Nucleotide sequences of the slt-IIB- and $s l t-I I B$-related genes present in $E$. coli non-O157 strains. The published ${ }^{12}$ slt- $I I B$ sequence is shown in the top line and compared with that of those B-subunit genes present in $\mathrm{O} 111: \mathrm{H}^{-} \operatorname{strain} 472 / 92, \mathrm{O}^{2} 28: \mathrm{H}^{-}$strain $284 / 89, \mathrm{ONT}^{-}$strain 199/92 and O22:H8 strain 469/87. The gene sequences are shown in descending order as described. For strain 199/92, both the slt-IIB- and the $s l t-I I$-related genes were sequenced and indicated ${ }^{a}$ and ${ }^{b}$ respectively. The nucleotides are numbered above the sequence. 
resulting from restriction endonuclease digestion with FokI and $\mathrm{Hae} \mathrm{III}$, respectively. Overall, it was predicted from these restriction endonuclease analyses that the PCR products consisted of $s l t-I I B$ in seven strains, slt$I I B$-related genes in one strain, and a mixture of slt-II and slt-II-related genes in the other.

\section{Southern blot hybridisation}

In addition to restriction endonuclease analyses, Southern hybridisation of genomic DNA from all nine strains possessing slt-II or slt-II-related genes was performed with the $s i t$-IIB probe. DNA samples from the non-toxigenic $E$. coli $\mathrm{C} 600$ and the slt-I-expressing strain E. coli $\mathrm{C} 600$ (H19J) were included as negative controls. In the positive control strain E. coli C600 (933W), which harbours slt-II, a single EcoRI fragment of $4.6 \mathrm{~kb}$ hybridised with the slt-IIB probe. The other positive control strain, which possesses slt-IIc, showed a fragment of $4.9 \mathrm{~kb}$ when hybridised with the slt-IIB probe. In EcoRI-digested DNA of strain $469 / 87$, a single fragment of $3.9 \mathrm{~kb}$ hybridised. In contrast, seven E. coli strains (7042/87, 928/91, 472/92, E-D31, E-D142, E-D147 and 284/89) demonstrated a single fragment of $4.6 \mathrm{~kb}$. In genomic DNA of strain 199/92, two EcoRI fragments of $3.9 \mathrm{~kb}$ and c. $7 \mathrm{~kb}$ hybridised with the probe. This is consistent with the presence of two genes belonging to the $s i t-I I$ family.

\section{Nucleotide sequence analysis by the Taq cycle sequencing method}

To definitively subtype the B-subunit genes, the fragments resulting from PCR with primers KS7/KS8 and GK3/GK4 were subjected to nucleotide sequence analysis. Before sequence analysis, the PCR product obtained from amplification with the primer pair GK3/GK4 was digested with FokI and HaeIII, as described above. The undigested fragments consisting of pure $s l t-I I$ or $s l t-I I B$-related genes were subjected to nucleotide sequence analysis. Comparing the sequences present in the $23 E$. coli strains, $100 \%$ homology with $s i t-I B$ or $s l t-I I B$ was revealed in all strains. Two strains possessed slt-IIB-related genes in addition to slt-IB or slt-IIB (fig. 1, table I). The Bsubunit genes of these strains possessed sequences that differed in three nucleotide bases from $\operatorname{sit}-I I c B$ but were identical to the published ${ }^{13}$ slt-IIvhcB sequence (fig. 2).

\section{Cytotoxic activity and neutralisation assay}

To determine whether the slt genes were expressed, and if genotyping correlated with current immunological SLT detection methods, all strains were subjected to cytotoxicity assays and the neutralisation test. When culture supernates were tested for cytotoxicity, all $23 \mathrm{E}$. coli isolates yielded similar cytotoxic activity $\left(10^{4}-10^{6} \mathrm{CD} 50 / \mathrm{ml}\right.$ of culture supernate). However, in the two strains expressing
SLT-IIvhc, the cytotoxic activity was not neutralised by antibodies against SLT-I or SLT-II or both.

\section{Discussion}

Shiga-like toxin (SLT)-producing E. coli strains are increasingly recognised as human pathogens causing a wide spectrum of illness including HUS. The great importance for public health lies in the fact that HUS leads to irreversible renal failure in a number of patients, necessitating dialysis or renal transplantation with the concomitant risks. The non-O157 E. coli strains isolated from patients with HUS belong to several different serogroups, E. coli O111 being predominant among the isolates from Italy and Germany. Both E. coli $\mathrm{O} 157$ and non-O157 strains have been shown to produce one or both of the two prototype SLTs-SLT-I and SLT-II. Much attention has been addressed previously to variant forms of SLT-II which were first characterised on a molecular basis in the $E$. coli $\mathrm{O} 91: \mathrm{H} 21$ strain B2F1 associated with HUS. ${ }^{15}$ More recently, SLT-II variants have been described in an E. coli O111 strain from a patient with $\mathrm{HUS}^{17}$ and in an E. coli $\mathrm{OX} 3$ strain isolated from a case of sudden infant death syndrome..$^{16}$

Recent epidemiological studies have verified the frequent presence of SLT-II-related toxins among $E$. coli $\mathrm{O} 157$ isolates. ${ }^{18,26,27}$ In this study, non-O157 E. coli isolates from patients with HUS were investigated to analyse the variability within the slt-II locus and to determine the prevalence of slt-II variants. The findings demonstrated that all strains had classical slt$I$ or $s l t-I I$, or both. Only two strains harboured slt-IIrelated genes and these were found together with either slt-I or slt-II. Even taking into account the small sample size, the infrequent detection of slt-II variants argues against the idea that these variants represent an important toxin component in non-O157 E. coli.

Comparison of the nucleotide sequences of the B subunit genes of the SLT-II variants with published sequences revealed $100 \%$ homology to slt-IIvhcB, a gene which was first described in E. coli $\mathrm{O} 157: \mathrm{H} 7$ strain $7279 .{ }^{13}$ The Taq cycle sequencing method, which takes advantage of thermostable DNA polymerase, was found to be a potentially attractive method for precise genotyping of the genes belonging to the slt-II family. However, if Taq-polymerase-mediated sequencing is performed before sequence analysis, digestion of the PCR products with FokI and HaeIII must be performed to exclude sequence errors due to the simultaneous presence of $s l t-I I$ - and slt-II-related genes in the PCR products. Because of its automation and its reduced template requirement, this method can be recommended for large-scale sequencing of slt genes in clinical isolates.

Other isolates of the three serogroups (O91, O111, O128) analysed here have been slt genotyped by other investigators, ${ }^{14,15,17}$ and have yielded different results. In E. coli O128: B12 strain H.I.8, slt-IIva was identified 
and shown to have the greatest divergence from slt-II described to date. ${ }^{14}$ The A-subunit gene exhibits $69.5 \%$, and the B-subunit gene $78.1 \%$ nucleotide sequence homology to the corresponding genes of sltII. We were unable to identify slt-IIva in E. coli $\mathrm{O} 128$ strain $284 / 89$, even with the use of primers specific for slt-IIvaB. Interestingly, the B-subunit gene of the $E$. coli $\mathrm{O} 128$ isolate analysed in the present study possessed $100 \%$ homology to slt-IIB sequences. Paton et $a l$. recently reported an $E$. coli $\mathrm{O} 111$ isolate from a patient with HUS that produced an SLT-II variant. ${ }^{17}$ In this study, E. coli $\mathrm{O} 111: \mathrm{H}^{-}$was the most frequent non-O157 serotype associated with sporadic cases of HUS, being found in 12 of 23 isolates. However, slt-IIrelated genes were not detected in any of these strains. Ten of the $15 E$. coli O111 strains had only slt-I sequences. In the remaining five strains, slt-I was present with a toxin gene that had $100 \%$ homology with the $s l t-I I B$ gene. Therefore, it is most likely that the toxin present in the $E$. coli O111 strains sequenced in our study was SLT-II. Additional SLT-II-related toxins with the greatest nucleotide sequence homology to slt-II have been shown to be present in E. coli O91:H21 strain B2F1. ${ }^{15}$ Two variant forms of slt-II,

\section{References}

1. Karmali MA, Petric M, Lim C, Fleming PC, Arbus GS, Lior H. The association between idiopathic hemolytic uremic syndrome and infection by verotoxin-producing Escherichia coli. J Infect Dis 1985; 151: 775-782.

2. Karch H, Heesemann J, Laufs R. Phage-associated cytotoxin production by and enteroadhesiveness of enteropathogenic Escherichia coli isolated from infants with diarrhea in West Germany. J Infect Dis 1987; 155: 707-715.

3. Bitzan M, Moebius E, Ludwig K, Müller Wiefel DE, Heesemann J, Karch H. High incidence of serum antibodies to Escherichia coli 0157 lipopolysaccharide in children with hemolytic-uremic syndrome. J Pediatr 1991; 119: 380-385.

4. Caprioli A, Luzzi I, Rosmini F et al. Hemolytic-uremic syndrome and Vero cytotoxin-producing Escherichia coli infection in Italy. $J$ Infect Dis $1992 ; 166: 154-158$.

5. Chart H, Smith HR, Scotland SM, Rowe B, Milford DV, Taylor CM. Serological identification of Escherichia coli O157:H7 infection in haemolytic uraemic syndrome. Lancet 1991; 337: 138-140.

6. Scotland SM, Rowe B, Smith HR, Willshaw GA, Gross RJ. Vero cytotoxin-producing strains of Escherichia coli from children with haemolytic uraemic syndrome and their detection by specific DNA probes. J Med Microbiol 1988; 25: 237-243.

7. Beutin L, Montenegro MA, Ørskov I et al. Close association of verotoxin (Shiga-like toxin) production with enterohemolysin production in strains of Escherichia coli. $J$ Clin Microbiol 1989; 27 : 2559-2564.

8. Bockemühl J, Aleksic S, Karch H. Serological and biochemical properties of Shiga-like toxin (verocytotoxin)-producing strains of Escherichia coli, other than O-group 157, from patients in Germany. Int J Med Microbiol Virol Parasitol Infect Dis 1992; 276: 189-195.

9. Karmali MA. Infection by verocytotoxin-producing Escherichia coli. Clin Microbiol Rev 1989; 2: 15-38.

10. Caprioli A, Luzzi I, Rosmini F et al. Communitywide outbreak of hemolytic-uremic syndrome associated with non-O157 verocytotoxin-producing Escherichia coli. J Infect Dis 1994; 169: 208-211. $v t \times 2 h a$ and $v t x 2 h b$, are both present in strain $\mathrm{B} 2 \mathrm{~F} 1$. They demonstrated $95.5 \%$ and $96.6 \%$ nucleotide sequence homology for the B-subunit genes, respectively, when compared to slt-IIB. The $E$. coli $\mathrm{O} 91$ strain $2343 / 89$ investigated in the present study possessed only the slt-I gene. However, the presence of an slt-IIrelated gene very similar to $v t \times 2 h a$ was verified in $E$. coli $\mathrm{O} 22: \mathrm{H} 8$ strain $469 / 87$ and in the ONT strain $199 / 92$. Both isolates were shown to harbour, in addition to slt-IIvhc, either slt-I (strain 469/87) or slt-II (strain 199/92).

Despite the use of advanced genotyping procedures, the prototype SLTs, and not the SLT-II variants, have been shown here to be predominant in non-O157 $E$. coli HUS isolates. However, it will be of interest to compare the prevalence of SLT-II variants in isolates from patients with diarrhoea and from asymptomatic carriers. This would enable a definitive statement to be made concerning their possible association with the pathogenesis of non-O157-associated disease.

We thank J. Heesemann, Würzburg, for helpful discussions and B. Plaschke for excellent technical assistance. This work was supported by the Deutsche Forschungsgemeinschaft Ka 717-2.
11. O'Brien AD, Tesh VL, Donohue Rolfe A et al. Shiga toxin: biochemistry, genetics, mode of action, and role in pathogenesis. Curr Top Microbiol Immunol 1992; 180: 65-94.

12. Schmitt CK, McKee ML, O'Brien AD. Two copies of Shiga-like toxin II-related genes common in enterohemorrhagic Escherichia coli strains are responsible for the antigenic heterogeneity of the $0157: \mathrm{H}^{-}$strain E32511. Infect Immun 1991; 59: 1065-1073.

13. Meyer T, Karch H, Hacker J, Bocklage H, Heesemann J. Cloning and sequencing of a Shiga-like toxin II-related gene from Escherichia coli $\mathrm{O} 157: \mathrm{H} 7$ strain 7279. Int J Med Microbiol Virol Parasitol Infect Dis 1992; 276: 176-188.

14. Gannon VP, Teerling C, Masri SA, Gyles CL. Molecular cloning and nucleotide sequence of another variant of the Escherichia coli Shiga-like toxin II family. J Gen Microbiol 1990; 36: 1125-1135.

15. Ito H, Terai A, Kurazono H, Takeda Y, Nishibuchi M. Cloning and nucleotide sequencing of Vero toxin 2 variant genes from Escherichia coli $\mathrm{O} 91: \mathrm{H} 21$ isolated from a patient with the hemolytic uremic syndrome. Microb Pathog 1990; 8: $47-60$.

16. Paton AW, Paton JC, Heuzenroeder MW, Goldwater PN, Manning PA. Cloning and nucleotide sequence of a variant Shiga-like toxin II gene from Escherichia coli OX3:H21 isolated from a case of sudden infant death syndrome. Microb Pathog 1992; 13: 225-236.

17. Paton AW, Paton JC, Manning PA. Polymerase chain reaction amplification, cloning and sequencing of variant Escherichia coli Shiga-like toxin type II operons. Microb Pathog 1993; 15: 77-82.

18. Rüssmann H, Schmidt H, Heesemann J, Caprioli A, Karch H. Variants of Shiga-like toxin II constitute a major toxin component in Escherichia coli O157 strains from patients with haemolytic uraemic syndrome. J Med Microbiol 1994; 40: $338-343$.

19. Bitzan M, Karch $H$, Maas MG et al. Clinical and genetic aspects of Shiga-like toxin production in traditional enteropathogenic Escherichia coli. Int $J$ Med Microbiol 1991; 274: 496-506.

20. Bockemühl J, Karch H, Rüssmann H, Aleksic S, Wiß R, Emmrich P. Transmission of Shiga-like toxin (Verotoxin)producing Escherichia coli $\mathrm{O} 22: \mathrm{H} 8$ by unpasteurized milk 
followed by a case of haemolytic-uraemic syndrome. Bundesgesundheitsblatt 1990; 1: 3-6.

21. Farina C, Gavazzeni G, Caprioli A, Remuzzi G. Hemolytic uremic syndrome associated with verocytotoxin-producing Escherichia coli infection in acquired immunodeficiency syndrome. Blood 1990; 75 : 2465.

22. Ricotti GC, Buonomini MI, Merlitti A, Karch H, Luzzi I, Caprioli A. A fatal case of hemorrhagic colitis, thrombocytopenia, and renal failure associated with verocytotoxin-producing, non $\mathrm{O} 157$ Escherichia coli. Clin Infect Dis 1994; 19: 815-816.

23. Stenger KO, Windler F, Karch H, von Wulffen $H$, Heesemann J. Hemolytic-uremic syndrome associated with an infection by verotoxin producing Escherichia coli $\mathrm{O} 111$ in a woman on oral contraceptives. Clin Nephrol 1988; 29: 153-158.

24. Karch H, Meyer T. Evaluation of oligonucleotide probes for identification of shiga-like-toxin-producing Escherichia coli. J Clin Microbiol 1989; 27: 1180-1186.

25. Schmidt H, Montag M, Bockemühl J, Heesemann J, Karch H. Shiga-like toxin II-related cytotoxins in Citrobacter freundii strains from humans and beef samples. Infect Immun 1993; 61: $534-543$

26. Thomas A, Smith HR, Rowe B. Use of digoxigenin-labelled oligonucleotide DNA probes for VT2 and VT2 human variant genes to differentiate vero cytotoxin-producing Escherichia coli strains of serogroup O157. J Clin Microbiol $1993 ; 31$ : 1700-1703.

27. Tyler SD, Johnson WM, Lior H, Wang G, Rozee KR. Identification of verotoxin type 2 variant $B$ subunit genes in Escherichia coli by the polymerase chain reaction and restriction fragment length polymorphism analysis. J Clin Microbiol 1991; 29: 1339-1343. 